\title{
Records of terrestrial and mangrove snails (Mollusca: Gastropoda) from the Michamwi Peninsula, Unguja (Zanzibar) Island (Tanzania)
}

\begin{abstract}
Dilian Georgiev
Department of Ecology and Environmental Conservation, University of Plovdiv, Tsar Assen Street 24, 4000 Plovdiv, Bulgaria, diliangeorgiev@gmail.com; https://orcid.org/0000-0003-2885-4895

Abstract: During a brief malacological survey, a total of 16 snail species were recorded (four mangrove amphibious, 12 terrestrial). For all the species new localities with GPS coordinates and habitat data are provided. The species Thapsia insulsa Preston, 1910 (Urocyclidae) is a new record to the island.
\end{abstract}

Keywords: Africa, amphibious, Gastropoda, new records, terrestrial

\section{Introduction}

Unguja, the main island of the Zanzibar Archipelago, lies about $6^{\circ}$ south of the equator and $40 \mathrm{~km}$ east of the mainland of Africa and has an area of approximately $1600 \mathrm{~km}^{2}$ (Pakenham, 1984). Most of the island is covered by high and low scrub forest, also known as a coral rag forest on ground characterised by numerous outcroppings of fossilised coral (Siex, 2011). This vegetation cover is classified as Eastern African Coastal Scrub Forest according to the Clarke's scheme (Burgess \& Clarke, 2000).

The East African coastal land mollusc fauna remains poorly explored (Verdcourt, 2006). The territory of Zanzibar autonomous region (Republic of Tanzania) is one of the best studied in terms of species composition of land snails (Rowson, 2007; Rowson et al., 2010; Gittenberger \& Bruggen, 2013) but many species have been reported without exact localities or they are problematic to find considering their names (Rowson, 2007). In this short note, I report of some exact species localities at the poorly known Michamwi Peninsula of the Unguja Island and one new record to the island malacofauna.

\section{Material and methods}

The study was carried out during the period 27.2.2021 -6.3 .2021 . A few closely situated localities were surveyed at the northernmost area of the Michamwi Peninsula, east coast of the Unguja Island (Michamwi is situated on the opposite side of the Chwaka Bay from the Jozani Forest). The specimens (dry shells) were collected by hand or by sieving of soil and detritus. Species names are following Rowson (2007) and Gittenberger \& Bruggen (2013).

\section{Results and discussion}

There were a total of 16 snail species recorded (four mangrove amphibious, 12 terrestrial). One of the terrestrial species is a new record to the fauna of the Un- 


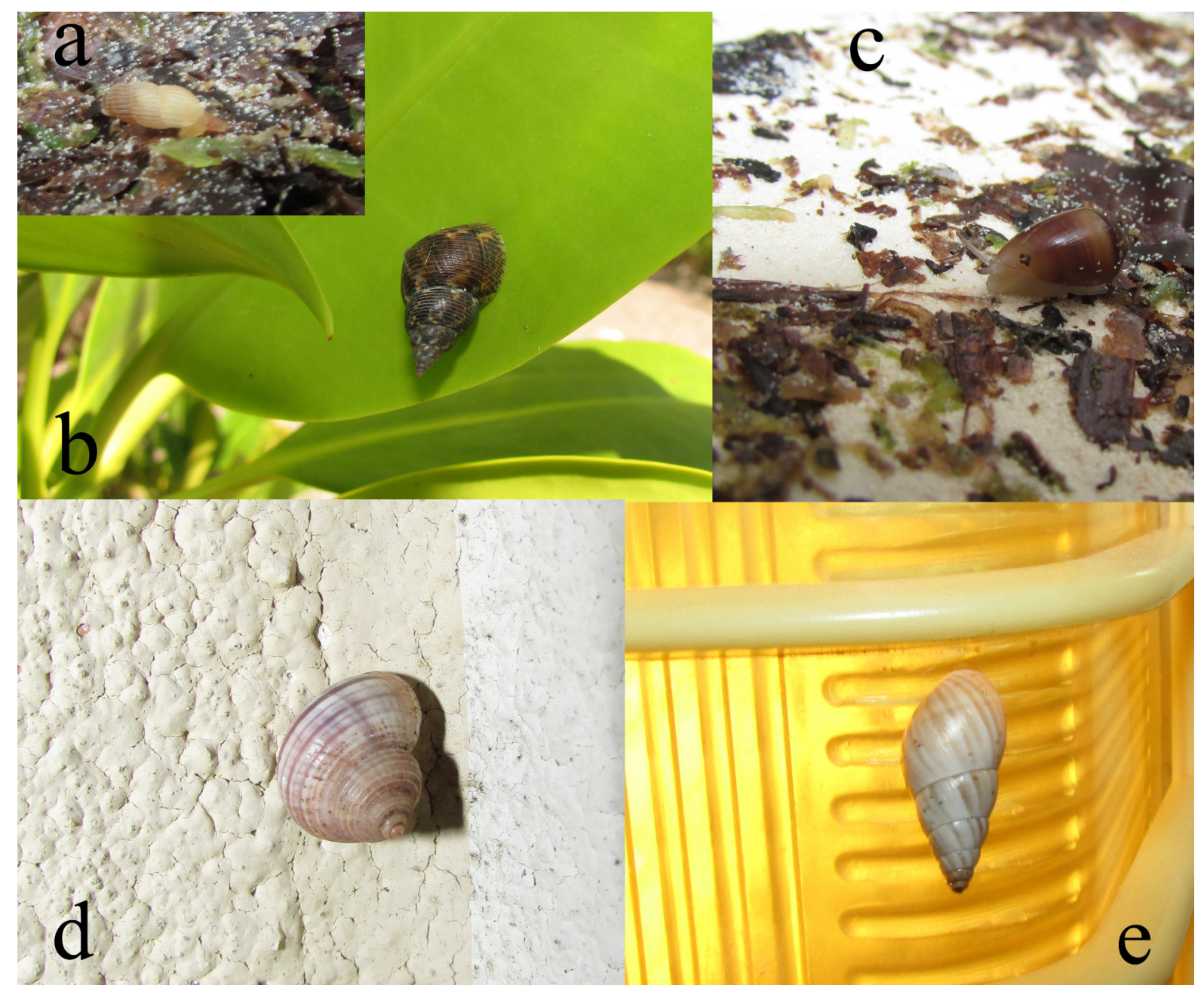

Fig. 1. Some of the living snail species recorded on the Michamwi Peninsula: (a) Truncatella guerinii (active specimen among detritus at low tide); (b) Littoraria intermedia (inactive, attached to a leaf of Avicennia marina); (c) Melampus luteus (active specimen among detritus and sand at low tide); (d) Tropidophora zanguebarica (inactive, attached to a wall); (e) Rachis punctata (inactive, attached to a lamp).

guja Island. For the rest of the species new localities with GPS coordinates and habitat data are provided.

\section{MANGROVE AMPHIBIOUS SPECIES}

\section{Littorinidae}

\section{Littoraria intermedia (Philippi, 1846)}

Material examined: 27.2.2021, mangrove dominated by Avicennia marina at a river estuary, south of the Michamwi Village, $\mathrm{S} 06^{\circ} 08^{\prime} 45.5^{\prime \prime} \mathrm{E} 39^{\circ} 29^{\prime} 22.9^{\prime \prime}, 5 \mathrm{~m}$ a.s.l., 1 shell and many living individuals observed (Fig. 1b); 2.3.2021, among rocks and various bushes at the periphery of the tidal zone, north-west coast of the peninsula, ${\mathrm{S} 06^{\circ}}^{\circ} 07^{\prime} 39.4^{\prime \prime} \mathrm{E} 39^{\circ} 29^{\prime} 28.2^{\prime \prime}, 2$ m a.s.1., many living individuals observed. This species is widespread in the mangroves of the tropics (Abbott \& Dance, 2000). In East Africa, it is rare in the coastal area of the continent but abundant on the nearby Pemba Island (Torres et al., 2008).

\section{Ellobiidae}

Melampus luteus (Quoy \& Gaimard, 1832)

Material examined: 27.2.2021, mangrove dominated by Avicennia marina at a river estuary, south of the 


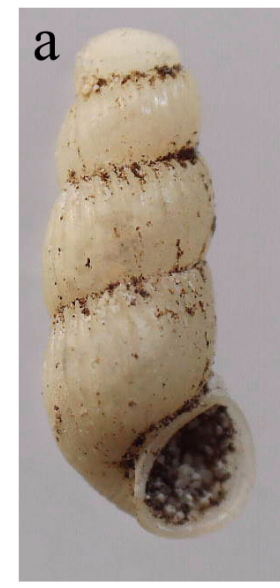

$\mathrm{H}=5.5 . \mathrm{mm}$

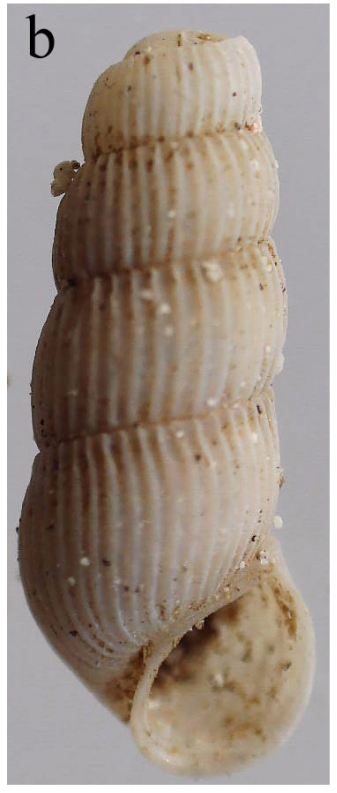

$\mathrm{H}=8.0 \mathrm{~mm}$
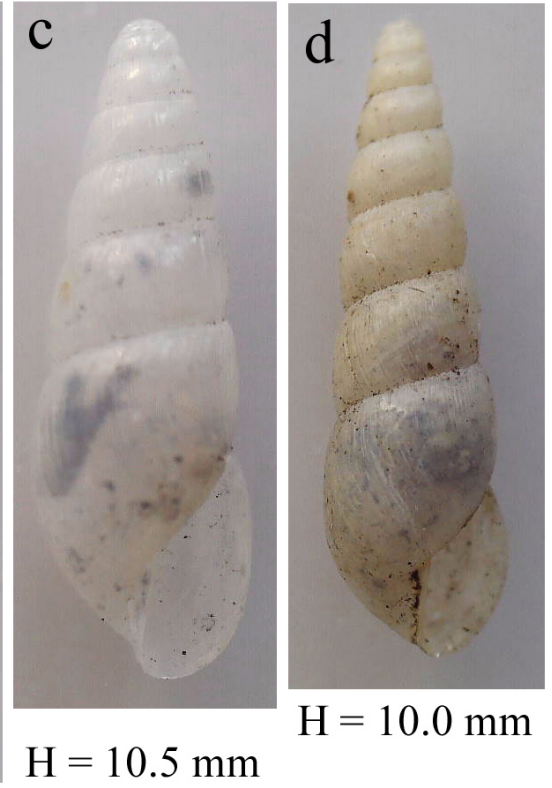

$\mathrm{H}=10.0 \mathrm{~mm}$

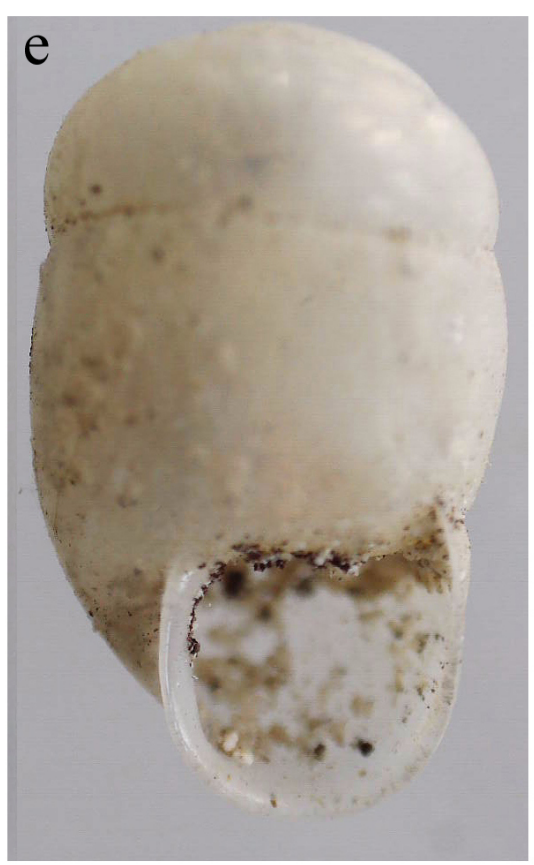

$\mathrm{H}=8.2 \mathrm{~mm}$

Fig. 2. Shells of some of the species collected: (a) Truncatella marginata, (b) T. guerinii, (c) Opeas lamoense, (d) Allopeas gracile, (e) Gonaxis gibbonsi.

Michamwi Village, $\mathrm{S} 06^{\circ} 08^{\prime} 45.5^{\prime \prime} \mathrm{E} 39^{\circ} 29^{\prime} 22.9^{\prime \prime}, 5 \mathrm{~m}$ a.s.l., 5 shells and many living individuals observed (Fig. 1c). Common estuarine species in the Indo-Pacific Region (Abbott \& Dance, 2000).

\section{Truncatellidae}

\section{Truncatella guerinii A. \& J.B. Villa, 1841}

Material examined: 27.2.2021, mangrove dominated by Avicennia marina at a river estuary, south of the Michamwi Village, ${\mathrm{S} 06^{\circ}}^{\circ} 08^{\prime} 45.5^{\prime \prime} \mathrm{E} 39^{\circ} 29^{\prime} 22.9^{\prime \prime}, 5 \mathrm{~m}$ a.s.l., 1 shell and many living individuals observed (Fig. 1a, 2b); 4.3.2021, Michamwi Village area, scattered bushes and trees on a sandy terrain, under rocks of a limestone hill, far from the tidal zone, $\mathrm{S} 06^{\circ}$ $08^{\prime} 17.5^{\prime \prime}$ E39 $2^{\circ} 9^{\prime} 38.8^{\prime \prime}, 5$ m a.s.1., 9 shells. Verdcourt (2006) mentioned T. guerinii from Zanzibar.

\section{Truncatella marginata Küster, 1855}

Material examined: 4.3.2021, Michamwi Village area, scattered bushes and trees on a sandy terrain, under

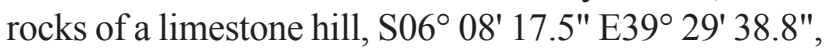
5 a.s.1., 5 shells (Fig. 2a). The species has a coastal dis- tribution from South Africa to the South Pacific (Muratov, 2010). Verdcourt (2006) mentioned T. marginata (as T. teres Pfeiffer, 1856, see Gittenberger \& Bruggen, 2013) from Zanzibar.

\section{TERRESTRIAL SPECIES}

\section{Pomatiasidae}

\section{Tropidophora zanguebarica (Petit, 1850)}

Material examined: 28.2.2021, Michamwi Village area, yard of a hotel, ${\mathrm{S} 06^{\circ}}^{\circ} 08^{\prime} 25.9^{\prime \prime} \mathrm{E} 39^{\circ} 29^{\prime} 26.4^{\prime \prime}, 3 \mathrm{~m}$ a.s.1., 3 living individuals, attached to a wall (Fig. 1d); 4.3.2021, Michamwi Village area, scattered bushes and trees on a sandy terrain, under rocks of a limestone hill, $\mathrm{S}^{\prime} 6^{\circ} 08^{\prime} 17.5^{\prime \prime} \mathrm{E} 39^{\circ} 29^{\prime} 38.8^{\prime \prime}, 5 \mathrm{~m}$ a.s.1., 14 shells and many more observed in the area. The species was known from the coastal regions of continental Africa (Kenya, Tanzania and Mozambique) and the closely situated islands. From the Unguja Island it has been recorded with an exact locality at the Jozani Forest (Rowson, 2007; Rowson et al., 2010; Muratov, 2010; Gittenberger \& Bruggen, 2013). 
Pupillidae

Pupoides coenopictus (Hutton, 1834)

Material examined: 28.2.2021, Michamwi Village area, yard of a hotel, S06 $08^{\prime} 25.0^{\prime \prime}$ E39 $9^{\circ} 9^{\prime} 33.0^{\prime \prime}, 7$ m a.s.1., 2 living individuals, attached to a wall. Widespread in sub-Saharan Africa, North Africa and Asia (Seddon, 1994). Reported for Zanzibar with no exact locality mentioned (Verdcourt, 1983). Considering Rowson et al. (2010), it is the first recent precise record of the species on the Zanzibar Archipelago.

\section{Cerastidae}

\section{Rachis punctata (Anton, 1839)}

Material examined: 28.2.2021, Michamwi Village area, yard of a hotel, S06 $08^{\prime} 25.0^{\prime \prime}$ E39 $9^{\circ} 9^{\prime} 33.0^{\prime \prime}, 7$ m a.s.1., 5 living individuals, attached to a wall and a lamp (Fig. 1e); 4.3.2021, Michamwi Village area, scattered bushes and trees on a sandy terrain, under rocks of a limestone hill, $\mathrm{S} 06^{\circ} 08^{\prime} 17.5^{\prime \prime} \mathrm{E} 39^{\circ} 29^{\prime} 38.8^{\prime \prime}, 5$ m a.s.l., 3 shells. Widespread and common species along the coasts of many countries bordering the tropical Indian Ocean and introduced to some areas of the Atlantic coast (Pilsbry, 1919; Rowson, 2007).

Subulinidae

Allopeas gracile (Hutton, 1834)

Material examined: 4.3.2021, Michamwi Village area, among grasses near a concrete wall, S06 $08^{\prime} 20.8^{\prime \prime}$ E39 ${ }^{\circ} 2^{\prime}$ 28.8", 3 m a.s.1., 2 shells (Fig. 2d). Verdcourt (1983) recorded it from the Unguja Island without mentioning an exact locality.

Homorus usagarica (E. A. Smith, 1890)

Material examined: 2.3.2021, Michamwi Village area, among grasses near a concrete wall, S06 ${ }^{\circ} 08^{\prime} 20.8^{\prime \prime}$ E39 ${ }^{\circ} 2^{\prime}$ 28.8", 3 m a.s.1., 1 shell; 4.3.2021, Michamwi Village area, scattered bushes and tree on a sandy terrain, under rocks of a limestone hill, S06 $08^{\prime} 17.5^{\prime \prime}$ E39 $9^{\circ} 9^{\prime} 38.8^{\prime \prime}, 5 \mathrm{~m}$ a.s.1., 5 shells. The species was reported for the island by Germain (1918) as "Zanzibar" (type locality of insularis syn. of usagarica, see
Rowson, 2007). Exact localities of this species on Unguja were not known till now.

Opeas lamoense Melvill \& Ponsonby, 1892

Material examined: 4.3.2021, Michamwi Village area, among grasses near a concrete wall, S06 ${ }^{\circ} 08^{\prime} 20.8^{\prime \prime}$ E39 29' 28.8", 3 m a.s.1., 2 shells (Fig. 2c). Verdcourt (1983) recorded it from Unguja Island without mentioning an exact locality. Rowson (2007) reported it from the Jozani Forest.

Pseudoglessula subolivacea (E. A. Smith, 1890)

Material examined: 4.3.2021, Michamwi Village area, scattered bushes and trees on a sandy terrain, under rocks of a limestone hill, S06 $08^{\prime} 17.5^{\prime \prime} \mathrm{E} 39^{\circ} 29^{\prime} 38.8^{\prime \prime}$, $5 \mathrm{~m}$ a.s.1., 7 shells. This species is common on the Unguja and Pemba Islands (Rowson, 2007; Rowson et al., 2010).

Achatinidae

Achatina (Lissachatina) allisa (L. Reeve, 1849)

Material examined: 4.3.2021, Michamwi Village area, scattered bushes and trees on a sandy terrain, under rocks of a limestone hill, S06 ${ }^{\circ} 08^{\prime} 17.5^{\prime \prime}$ E39 29' 38.8", $5 \mathrm{~m}$ a.s.1., 6 shells. Common along the East African coast and in the adjacent areas, including the islands (Mead, 1995). The only exact locality (Jozani Forest) on the Unguja Island was reported by Rowson (2007).

Achatina (Lissachatina) reticulata (L. Pfeiffer, 1845)

Material examined: $27.02-6.3 .2021$, Michamwi Village area, many shells observed (often broken and at fire sites with traces of possible human consumption or other use). Native to East Africa, mainly coastal species reported from many localities on the Unguja Island (Bequaert, 1950; Rowson, 2007).

Streptaxidae

Gonaxis gibbonsi Taylor, 1877

Material examined: 3.3.2021, Michamwi Village area, scattered bushes and trees on a sandy terrain, under 


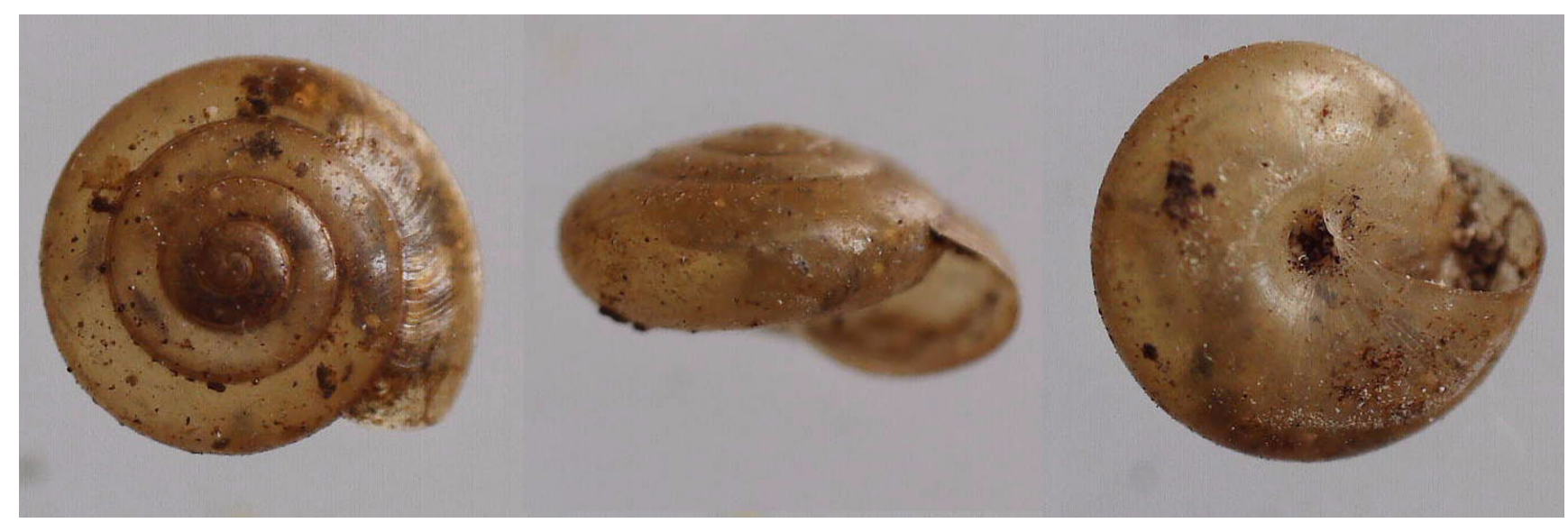

Fig. 3. Shell of Thapsia insulsa from the Michamwi Peninsula, Unguja Island ( $\mathrm{D}=3.8 \mathrm{~mm})$.

rocks of a limestone hill, ${\mathrm{S} 06^{\circ}}^{0} 08^{\prime} 17.5^{\prime \prime} \mathrm{E} 39^{\circ} 29^{\prime} 38.8^{\prime \prime}$, $5 \mathrm{~m}$ a.s.1., 2 shells; 4.3.2021, same locality, 3 shells (Fig. 2e). The species was known from continental Tanzania (Usambara Mts) and Kenya (Taita Hills), and from Zanzibar (without an exact locality) (Taylor, 1877; Verdcourt, 1983; Rowson, 2007). It was reported from the Unguja Island at the Chwaka Bay area by Rowson (2007).

\section{Ariophantidae}

\section{Sitala jenynsi (L. Pfeiffer, 1845)}

Material examined: 4.3.2021, Michamwi Village area, scattered bushes and trees on a sandy terrain, under rocks of a limestone hill, S06 $08^{\prime} 17.5^{\prime \prime} \mathrm{E} 39^{\circ} 29^{\prime} 38.8^{\prime \prime}$, $5 \mathrm{~m}$ a.s.1., 8 shells, and many more observed at the area. Lowland coastal species, known from Kenya, Tanzania and Mozambique and some closely situated islands (Verdcourt, 1963). From the Unguja island it was reported with an exact locality only by Rowson (2007) at the Jozani Forest.

\section{Urocyclidae}

\section{Thapsia insulsa Preston, 1910}

Material examined: 3.3.2021, Michamwi Village area, scattered bushes and trees on a sandy terrain, under rocks of a limestone hill, ${\mathrm{S} 06^{\circ}}^{\circ} 08^{\prime} 17.5^{\prime \prime} \mathrm{E} 39^{\circ} 29^{\prime} 38.8^{\prime \prime}$,
$5 \mathrm{~m}$ a.s.l., 2 shells (Fig. 3). The type locality of this species is in Kenya and was recently recorded from the nearby Pemba Island by Rowson et al. (2010). New record for the Unguja Island.

\section{Acknowledgements}

I am grateful to Ben Rowson (National Museum of Wales, UK) for the literature sent and the useful discussions.

\section{References}

Abbott R., Dance S. 2000 Compendium of Seashells. Odyssey Publications, $411 \mathrm{pp}$.

Bequaert J. 1950 Studies in the Achatininae, a group of African land snails. Bulletin of the Museum of Comparative Zoology, Harvard 105: 1-216.

Burgess N., Clarke G. 2000 Coastal Forests of Eastern Africa. IUCN, Cambridge, 42 pp.

Germain L. 1918 Contributions à la Faune Malacologique de L'Afrique Équatoriale. LII: Sur quelques Mollusques terrestres de Zanzibar. Bulletin de la Musee de 1'Histoire Naturelle de Paris 4: 131-150.

Gittenberger E., Van Bruggen A. 2013 Land snails of the islet of Misali. Zoologische Mededelingen 87 (3): 235-273.

Mead A. 1995 Anatomical studies reveal new phylogenetic interpretations in Lissachatina (Pulmonata: 
Achatinidae). Journal of Molluscan Studies 61: 257-273.

Muratov I. 2010 Terrestrial molluscs of Cabo Delgado and adjacent inland areas of north-eastern Mozambique. African Invertebrates 51: 255-288.

Pakenham R. 1984 The Mammals of Zanzibar and Pemba Islands. Printed privately, Harpenden, UK, $81 \mathrm{pp}$.

Pilsbry H. 1919 A review of the land Mollusks of the Belgian Congo chiefly based on the collections of the American Museum Congo Expedition, 1900-1915. Bulletin of the American Museum of Natural History 40: 1-370.

Rowson B. 2007 Land molluscs of Zanzibar Island (Unguja), Tanzania with the description of a new species of Gulella (Pulmonata: Streptaxidae). Journal of Conchology 39 (4): 425-466.

Rowson B, Warren B.H., Ngereza C.F. 2010 Terrestrial molluscs of Pemba Island, Zanzibar, Tanzania, and its status as an "oceanic" island. ZooKeys 70: 1-39.

Seddon M. 1994 The distribution of Pupoides coenopictus (Hutton, 1834) in NW Africa (Gastropoda: Pupillidae). Journal of Conchology 34: 299-310.
Siex K. 2011 Protected Area Spatial Planning for Unguja and Pemba Islands, Zanzibar. Final Consultancy Report. Wildlife Conservation Society, New York, 42 pp.

Taylor J.W. 1877 Descriptions of new species of land shells from the East coast of Africa. Quarterly Journal of Conchology 1: 280-283.

Torres P., Alfiado A., Glassom D., Jiddawi N., Macia A., Reid D., Paula J. 2008 Species composition, comparative size and abundance of the genus Littoraria (Gastropoda: Littorinidae) from different mangrove strata along the East African coast. Hydrobiologia 614: 339-351.

Verdcourt B. 1963 A Note on Sitala jenynsi Pfeiffer (Helicarionidae). Journal of Conchology 25: 188-192.

Verdcourt B. 1983 A list of the non-marine Mollusca of East Africa (Kenya, Uganda, Tanzania, excluding Lake Malawi). Achatina 11: 200-239.

Verdcourt B. 2006 A revised list of the non-marine Mollusca of East Africa (Kenya, Uganda, Tanzania, excluding Lake Malawi). Maidenhead, 75 pp. 